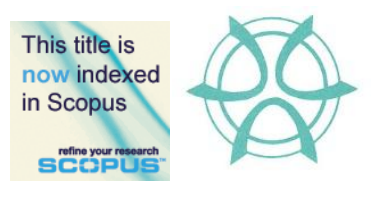

PLANNING MALAYSIA:

Journal of the Malaysian Institute of Planners

Volume XII (2014), Page 105 - 132

\title{
ANALYSIS ON COMMUNITY INVOLVEMENT IN CULTURAL ACTIVITIES: TRANSMISSION OF ETHNIC LANGUAGE
}

\author{
Aisyah Abu Bakar', Mariana Mohamed Osman ${ }^{2}$, Syahriah Bachok ${ }^{3}$ \& \\ Mansor Ibrahim ${ }^{4}$ \\ ${ }^{1,2,3 \& 4}$ Kulliyyah of Architecture and Environmental Design \\ INTERNATIONAL ISLAMIC UNIVERSITY MALAYSIA
}

\begin{abstract}
This research reviews an analysis of Community Involvement in Cultural Activities specifically from the angle of transmission of Ethnic Language. Convention for the Safeguarding of Intangible Cultural Heritage (ICH) which has been adopted by UNESCO in October, 2003 has aimed to raise awareness at the local, national and international levels of the significance $\mathrm{ICH}$, to ensure ICH is mutually respected by the communities concerned and to provide assistance for education and fund for the maintenance of this heritage. Survey Questionnaires have been recently conducted in one of the World Heritage Site, Melaka; to measure and determine the level of community involvement in cultural activities. The survey adopts five domains of ICH, Oral Tradition, Performing Arts, Knowledge, Social Practices and Traditional Craftsmanship in determining the involvement level of four cultured communities in their cultural enactments. These four communities are selected geographically. They are Morten Village Community, Portuguese Village Community, Heren and Jonker Streets Community and Gajah Berang Village Community. This paper acknowledges the significance, similarities and differences of the four cultured communities especially on transmission of ethnic languages with regards to community characters, specifically demographic and socioeconomic factors. Finally the analysis evaluates on the significance ethnic language transmission towards the overall cultural manifestations of the cultural communities.
\end{abstract}

Keywords: Ethnic Language, Language Forms, Language Experience, Language Shift, Intangible Cultural Heritage.

${ }^{1}$ Postgraduate Student (PhD). Email: isya.ab@ gmail.com

${ }^{2}$ Associate Professor at KAED, IIUM, Malaysia. Email: mariana@iiu.edu.my

${ }^{3}$ Assistant Professor at KAED, IIUM, Malaysia. Email: syahriah@iiu.edu.my

${ }^{4}$ Professor at KAED, IIUM, Malaysia. Email: 
Aisyah Abu Bakar, Mariana Mohamed Osman, Syahriah Bachok \& Mansor Ibrahim

Analysis on Community Involvement in Cultural Activities: Transmission of Ethnic Language

\section{INTRODUCTION}

For over 600 years since Malacca was founded, Malaysia is now inhabited by more than 50 ethnic groups of diverse languages and dialects. With interesting history and variety of architectural and other cultural heritages, Malaysia has turned into mosaics of cultures. Although the official language in Malaysia is the Malay language, other languages such as Mandarin, Tamil, Cristao, Malay Creoles and many others need to be acknowledged. These languages are the vehicles connecting one cultural community to the other as well as a tool in transferring knowledge from one generation to the next.

A phenomenon addressed as 'Language Shift' occurs when a language is displaced by another along the lives of community members. Among the factors contributing to this phenomenon are demographic declination, Interlingua distance, dialect diversity, writing system and mass media (Huebner T., 1987). The phenomenon of language shift also occurs in Malaysia whereby one of the contributing factors are the use of English has once been adapted in text books and is also employed in discourses in school classes and social interaction. Other than the fact that there are varieties of Malay dialects articulated among the citizens, Malaysians being a multiracial society are typically to experience interethnic (Asmah O., 2004). Thus it is possible for the official Malay language, and perhaps other languages used in Malaysia to experience language shift. Therefore acknowledging diversity of languages in a particular cultural community is crucial to determine if the culture has been genuinely transmitted or passed on. This also establishes the degree of understanding and involvement of a certain individual to his cultural community.

Survey Questionnaires have been recently conducted in one of the World Heritage Sites, Melaka, inquiring four cultural communities to address their level of involvement in social and cultural clubs. These four communities are selected geographically. They are Morten Village Community, Portuguese Village Community, Heren and Jonker Streets Community and Gajah Berang Village Community. Research hypothesis addresses that different communities have different level of language practice and that the differences are caused by the significance of community demographic and socio-economic characters. 
In order to prove so, the sample from the questionnaires is analyzed by employing suitable SPSS statistical tests. In consistent with the primary hypothesis, subsequent hypotheses are addressed for each statistical test in supporting the primary hypothesis.

\section{PRACTICE OF ETHNIC LANGUAGE}

Ethnic Language is referred to the language which is highly associated with the respondents' ethnic background. In this research, the case studies namely Morten Village, Portuguese Village, Heren and Jonker Street and Gajah Berang Village are selected because of the minority cultured communities who are claimed to reside in the four locations. The cultured communities are Traditional Malays, Chetty, Portuguese and Baba and Nyonya. It is presumed that the respondents from the cultural community speak their Ethnic Language. Therefore, Chetty respondents speak Malay Creole Chetty, Baba and Nyonya respondents speak Malay Creole Baba, Portuguese respondents speak Cristao, Indian respondents speak Tamil, Chinese respondents speak Cantonese, Mandarin or Hokkien and lastly Malay respondents speak Malay.

However, it is discovered that only $60 \%$ of the respondents recognize their Ethnic Language as their Mother Tongue and Spoken Language, 2\% of the respondents recognize Ethnic Language as Spoken Language but not Mother Tongue, and 38\% of the respondents no longer recognize their Ethnic Language as Spoken Language or Mother Tongue. Additionally, 30\% of the respondents recognize Ethnic Language as their Mother Tongue but not their Spoken Language. This implies that transmission of Ethnic Language is deteriorating. Furthermore, $6 \%$ of the respondents recognize English as their Mother Tongue and Spoken Language. English is considered a popular Spoken Language since $36 \%$ of the respondents speak English regardless of their Mother Tongue.

Despite the fact that the statistical evidence implies that Ethnic Language practice is deteriorating, majority of the respondents claim that they still practice their Ethnic Language occasionally. Therefore, regardless if their Mother Tongue and Spoken Language are not their Ethnic Language, Ethnic Language is still recognized and practiced in certain occasion. 
Aisyah Abu Bakar, Mariana Mohamed Osman, Syahriah Bachok \& Mansor Ibrahim

Analysis on Community Involvement in Cultural Activities: Transmission of Ethnic Language

\section{ANALYSIS ON FACTORS INFLUENCING PRACTICE OF ETHNIC LANGUAGE}

Ethnic Language Practice is a dichotomous variable which determines whether the respondents are either Ethnic Language Practitioners or NonPractitioners. Chi-Square for Independence tests are implemented to assess if there are relationships between any of the demographic and socioeconomic variables with Ethnic Language Practice variable. The results of the tests are shown in Table 16.

Table 16: Summary of Chi-Square for Independence Results for Ethnic Language Practice with Demographic and Socio-Economic Variables and Club Participation Variables

\begin{tabular}{lllllll}
\hline \multicolumn{1}{c}{$\begin{array}{c}\text { There are no relationships between } \\
\text { following variables }\end{array}$} & Ethnic Language & Practice and the \\
\hline \multicolumn{7}{c}{ There are significant relationships between Ethnic Language Practice and the } \\
following variables
\end{tabular}


PLANNING MALAYSIA

Journal of the Malaysia Institute of Planners (2014)

\begin{tabular}{|c|c|c|c|c|c|c|c|}
\hline Occupation & $\begin{array}{l}\text { Nomin } \\
\text { al }\end{array}$ & 7 & $50.973^{a}$ & $\begin{array}{l}14.0 \\
67\end{array}$ & 0.000000 & $<0.05$ & Reject $\mathrm{H}_{\mathrm{o}}$ \\
\hline $\begin{array}{l}\text { Jobs Promote } \\
\text { Culture? }\end{array}$ & $\begin{array}{l}\text { Nomin } \\
\text { al }\end{array}$ & 1 & $6.243^{\mathrm{a}}$ & $\begin{array}{l}3.84 \\
1\end{array}$ & 0.012472 & $>0.05$ & Reject $\mathrm{H}_{\mathrm{o}}$ \\
\hline $\begin{array}{l}\text { Education } \\
\text { Level }\end{array}$ & Ordinal & 3 & $20.604^{\mathrm{a}}$ & $\begin{array}{l}7.81 \\
5\end{array}$ & 0.000127 & $<0.05$ & Reject $\mathrm{H}_{\mathrm{o}}$ \\
\hline $\begin{array}{l}\text { Household } \\
\text { Income Cat. }\end{array}$ & Interval & $\begin{array}{l}1 \\
0\end{array}$ & $91.143^{\mathrm{a}}$ & $\begin{array}{l}18.3 \\
07\end{array}$ & 0.000000 & $<0.05$ & Reject $\mathrm{H}_{\mathrm{o}}$ \\
\hline $\begin{array}{l}\text { Household } \\
\text { Members Cat. }\end{array}$ & Interval & 2 & $13.485^{\mathrm{a}}$ & $\begin{array}{l}5.99 \\
1\end{array}$ & 0.003698 & $<0.05$ & Reject $\mathrm{H}_{\mathrm{o}}$ \\
\hline
\end{tabular}

According to Table, the summary of Chi-Square results indicates 12 factors which influence Ethnic Language Practice. The outcome summary implies that between subjects of the 12 factors highlighted in the table, the observed counts of Ethnic Language Practitioners have deviated from the expected counts which consequently results in statistically significant value of $\chi 2$. As the amount of deviation increases, the value of $\chi 2$ also increases and $p$ value retreats from 0.05 . The lesser the $\mathrm{p}$ value from 0.05 , the more significant is the value of $\chi 2$. Thus for the 12 factors, the Chi-Square tests reject the null hypothesis. This means that there are relationships between the 12 factors and Ethnic Language Practice. On the other hand, two factors namely Gender and Work have no relationships with Ethnic Language Practice, $p$ > 0.05 . Table 17 is the interpretation of results for the 12 significant factors.

Table 17: Chi-Square for Independence Interpretation of Results for Ethnic Language Practice with Significant Related Factors

\begin{tabular}{lll}
\hline Decision: $\mathrm{REJECT} \mathrm{H}_{0}$ (There is a significant relationship) \\
\hline DV: Ethnic Language Practice
\end{tabular}


Aisyah Abu Bakar, Mariana Mohamed Osman, Syahriah Bachok \& Mansor Ibrahim

Analysis on Community Involvement in Cultural Activities: Transmission of Ethnic Language

counts of married respondents who practice ethnic language compared to single respondents who practice ethnic language.

Reasoning: The weak association between Ethnic Language Practice and Marital Status indicates that most ethnic language practitioners are married, however the likelihood is not too convincing. Married respondents have more family interaction compared to single respondents. Majority of married respondents have the same ethnicaffiliated partners. Thus explains how being married have higher possibility to practice ethnic language compared to being single. On the other hand, majority of single respondents experience schools and work environment, therefore tendencies of interaction with non-ethnic affiliated acquaintances are higher and more than married respondents. Additionally, it is discovered that $50 \%$ of single respondents consider English as their Spoken Language. Therefore infers that it is unlikely for the members of the cultural community who are single to practice ethnic language.

- There is a highly statistically significant relationship between Ethnic Language Practice and Age Categories,

- $\quad x^{2}(6)=47.50, \mathrm{p}=$ $0.00<0.01$.

- Measure of Association:

Age $\quad$ Eta : $0.272, \mathrm{p}=0.00$

Categories *The greater the age of respondents, the more likely they practice ethnic language Language Practice and Age Categories indicates that as the respondents' age increases, the more likely the respondents practice ethnic language, although the likelihood is not too convincing. It is discovered that less than half of the respondents who are below 40 years old practice ethnic language. On the other hand, there are $72 \%$ of respondents who are above 40 years old practice ethnic language. Based on this finding, there are two sides of inferences which can be addressed. First is that practice and transmission of ethnic language of 
PLANNING MALAYSIA

the drastically declining. It is found that $50 \%$ of respondents who are below 40 years old consider English as spoken language, and $25 \%$ of respondents who are above 40 years old consider English as spoken language. English is the most popular spoken language of the younger generation of the cultural community, compared to their ethnic language. Secondly, this also infers that ethnic languages may still be articulated in the cultural community however they are greatly practiced by the older generation compared to younger generation. This is because interaction with people of different ethnicity such as in schools and working environment reduces as age increases. At the same time, interaction with family members who tend to be ethnicaffiliated people increases as age increases. This encourages the use of ethnic language as spoken language as respondents grow older.

Location of Residence
- Frequency of ethnic language practitioners in every location is significantly different. This means ethnic language practice is significantly influenced by location of residence.

- Cramer's V of 0.622 indicates a strong association between Location of Residence and Ethnic Language Practice.

- There are significantly high observed counts than expected counts of ethnic language practitioners who live in Morten Village, Gajah Berang Village and Heren and Jonker Streets respectively. Only $15 \%$ respondents from Portuguese Village practice their ethnic language.

Reasoning: The strong association between Ethnic Language Practice and Location of Residence points out that there is a strong likelihood of respondents from Portuguese Village not to practice their ethnic language, while respondents from Morten Village, Heren and Jonker Streets and Gajah Berang Village to practice their ethnic language. All respondents from Portuguese Village are Portuguese descendants thus their ethnic language is Cristao which is among the least common spoken languages in Malaysia. As the Portuguese 
Aisyah Abu Bakar, Mariana Mohamed Osman, Syahriah Bachok \& Mansor Ibrahim

Analysis on Community Involvement in Cultural Activities: Transmission of Ethnic Language

respondents interact with other people outside their village, Cristao is no longer a widely comprehensible language. This has become a difficulty for the Portuguese residents in Malaysia to practice Cristao as a spoken language. Although $36 \%$ of the Portuguese respondents' mother tongue is Cristao, only $15 \%$ of them speak Cristao. Instead, English is the most widely used language in Portuguese Village. In addition, the only $15 \%$ of the Portuguese's Village respondents who still speak Cristao age above 50 years old. This suggests that apart from having difficulty in practicing Cistao, the use of Cristao in Portuguese Village is highly deteriorating and poorly transmitted to the younger generation. In contrast, all respondents from Morten Village, and majority of Gajah Berang Village and Heren and Jonker Streets respondents are still practicing their ethnic languages; which are mostly Malay, Creole Malay and Mixed or Traditional Chinese. Since these ethnic languages are widely conversed and comprehensible in Malaysia, the difficulty to practice ethnic language for respondents from the three locations is significantly less than respondents from Portuguese Village.

Origin

(Native/

Non-native)
- Frequency of native and non-native ethnic language practitioners is significantly
- There is a highly statistically significant relationship between Ethnic Language Practice and Origin,

- $\quad x^{2}(1)=12.242, \mathrm{p}=$ $0.00<0.01$

- Measure of Association: Phi: $-0.143, p=0.000$ different. This means ethnic language practice is significantly influenced by origin.

- However, Phi of -0.143 indicates a very weak negative association between Origin and Ethnic Language Practice

- There are significantly high observed counts than expected counts of ethnic language practitioners who are non-native to their location of residence.

Reasoning: A very weak association between Ethnic Language Practice and Origin indicates that ethnic language practitioners are likely non-native to their location, although the likelihood is not too convincing. It is discovered that the observed counts of non-native ethnic language practitioners are only higher than expected counts for Morten Village, Gajah Berang Village and Heren and Jonker Streets. It is not surprising for all the non-native respondents in Morten Village to practice their ethnic language since all of them are Malays and Malay is the national language of Malaysia. However for Gajah 
PLANNING MALAYSIA

Berang Village, Chetty Creole Malay is practiced by majority of the non-native respondents. This implies a possibility that most of the non-native residents of Gajah Berang Village originate from areas where Chetty Creole Malay is widely practiced. Additionally, this also suggests that the non-native respondents have adapted well with majority of Chetty residents in the village, thus enable them to enhance the use of Chetty Creole Malay. In Heren and Jonker Streets, $27 \%$ of native respondents of Heren and Jonker Streets practice English while nearly half of the non-native respondents speak English. However, majority of both native and non-native respondents still speak their ethnic language, which is mostly Mixed or Traditional Chinese. The language is also among commonly used languages in Malaysia by the Chinese people. Unlike the three locations, majority of non-native respondents from Portuguese Village speak English instead of their ethnic language. Since majority of the native residents in Portuguese Village speak English too, thus the possibility for the non-native residents to learn Cristao from the native residents is bleak.

Duration of

Residence

Categories
- There is a highly statistically significant relationship between Ethnic Language Practice and Duration of Residence Categories,

- $\quad x^{2}(8)=30.085, \mathrm{p}=$ $0.00<0.01$

- Measure of Association:

Eta: 0.241

*The greater the duration of residence of the respondents, the more likely they practice ethnic language
- Frequency of ethnic language practitioners in every category of duration of residence is significantly different. This means ethnic language practice is significantly influenced by duration of residence categories.

- However, Eta of 0.241 indicates a weak positive association between Duration of Residence Categories and Ethnic Language Practice

- There are significantly high observed counts than expected counts of ethnic language practitioners who have settled in their respective locations for more than 40 years

Reasoning: The positive yet weak association between Ethnic Language Practice and Duration of Residence Categories indicates that the longer the respondents' duration of residence, the more likely the respondents practice ethnic language, although the likelihood is not too convincing. It is discovered that most ethnic language 
Aisyah Abu Bakar, Mariana Mohamed Osman, Syahriah Bachok \& Mansor Ibrahim

Analysis on Community Involvement in Cultural Activities: Transmission of Ethnic Language

practitioners are respondents who have settled in for more than 40 years. This suggests that the longer the respondents stayed in their respective locations, the more likely ethnic language is practiced as spoken language by the respondents. Since ethnicity is a geographical driver of the cultural community, communication with the existing community influences the use of ethnic language. This means that duration of residence determines the length of interaction which certain individuals experience with their community. The length of interaction represents profoundness of community bridge, which at the same time encourages the community to speak in a language that shows a sense of belonging to each other and to the place. However, since the measure of association indicates a weak positive relationship of 0.241 , this means that the practice of ethnic language which results from this interaction is deteriorating. This may be due to several reasons, one of which is the use of ethnic language in the place itself is deteriorating. At the same time, interaction between the individuals in the community can also be declining.

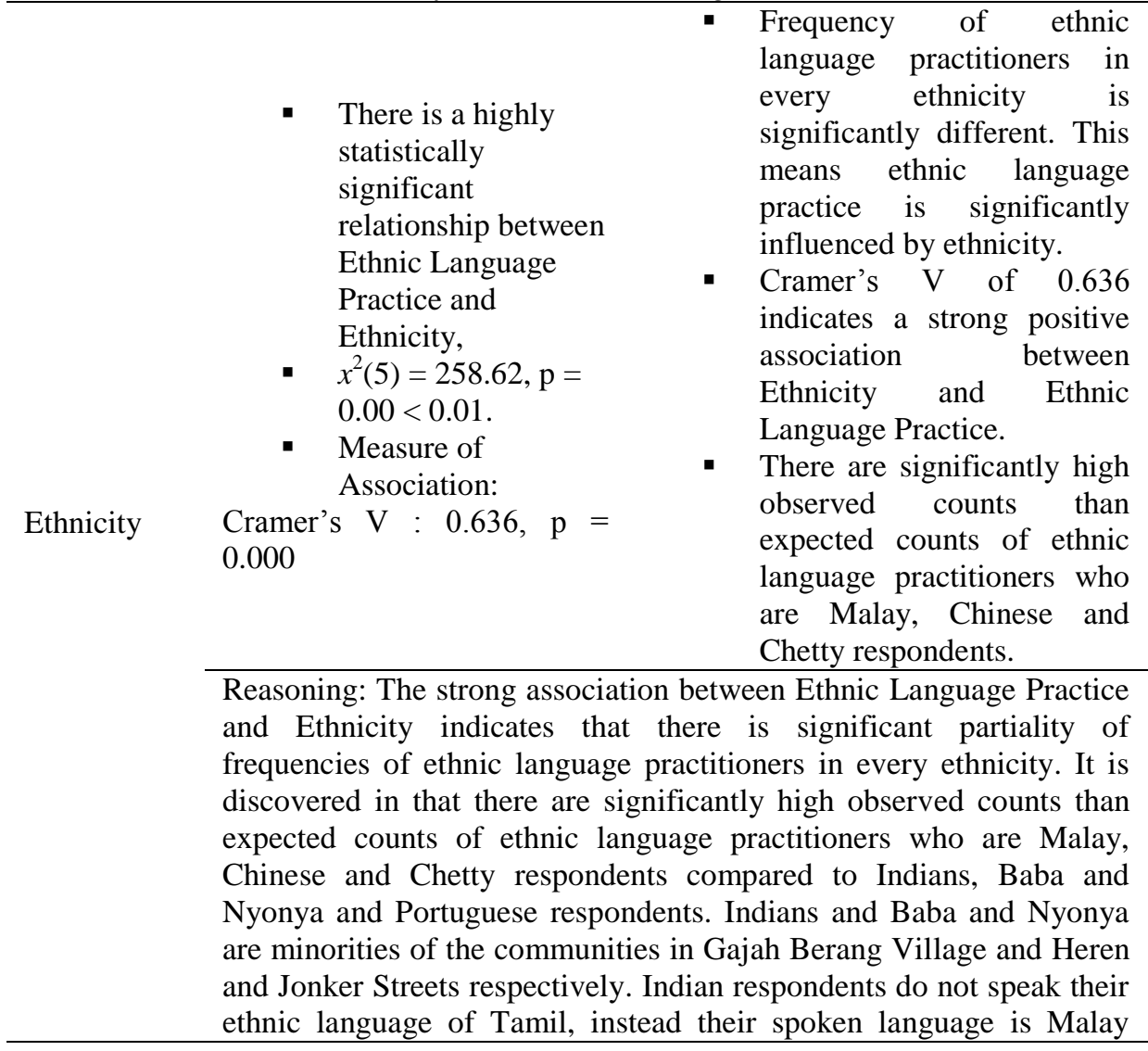


PLANNING MALAYSIA

Journal of the Malaysia Institute of Planners (2014)

Creole Chetty, alongside with the Chetty respondents who are majority residents of Gajah Berang Village. Although $60 \%$ of Baba and Nyonya respondents still speak Malay Creole Baba, vast majority of them are above 60 years old. The rest of Baba and Nyonya respondents speak Mixed or Traditional Chinese, alongside with the Chinese respondents who are majority residents of Heren and Jonker Streets. Two inferences can be addressed from this finding. From a positive angle, this implies that there is a strong community bridge between Indians and Chetty respondents as well as between Chinese and Baba and Nyonya respondents. However, from a negative angle, this has caused deteriorations of ethnic language practice for minorities like Indian and Baba and Nyonya respondents when they adapted with majority residents of their locations. A different case for the Portuguese who are ethnic minority of the country that have among the least comprehensible ethnic languages; hence it is unsurprising for them to face difficulties in practicing Cristao.

- There is a highly statistically significant relationship between Ethnic Language Practice and Religion,

- $\quad x^{2}(4)=255.17, \mathrm{p}=$ $0.00<0.01$.

- Measure of Association:

Religion Cramer's V : $0.631, \mathrm{p}=$ 0.000
- Frequency of ethnic language practitioners in every religion is significantly different. This means ethnic language practice is significantly influenced by religion.

- Cramer's V of 0.631 indicates a strong positive association between Religion and Ethnic Language Practice.

- There are significantly high observed counts than expected counts of ethnic language practitioners who believe in Islam, Buddhism and Hinduism.

Reasoning: The strong association between Ethnic Language Practice and Religion indicates that there is a significant partiality of frequencies of ethnic language practitioners for every religion. Since religion variable is strongly associated with ethnicity variable (all Malay respondents believe in Islam, most Chinese respondents believe in Buddhism and most Chetty respondents believe in Hinduism), therefore observed counts of ethnic language practitioners are higher than expected counts for Islam, Buddhism and Hinduism.

\begin{tabular}{llll}
\hline Occupation & $\begin{array}{l}\text { There is a highly } \\
\text { statistically }\end{array}$ & - $\begin{array}{l}\text { Frequency of ethnic } \\
\text { language practitioners in }\end{array}$ \\
\cline { 2 - 4 }
\end{tabular}


Aisyah Abu Bakar, Mariana Mohamed Osman, Syahriah Bachok \& Mansor Ibrahim

Analysis on Community Involvement in Cultural Activities: Transmission of Ethnic Language

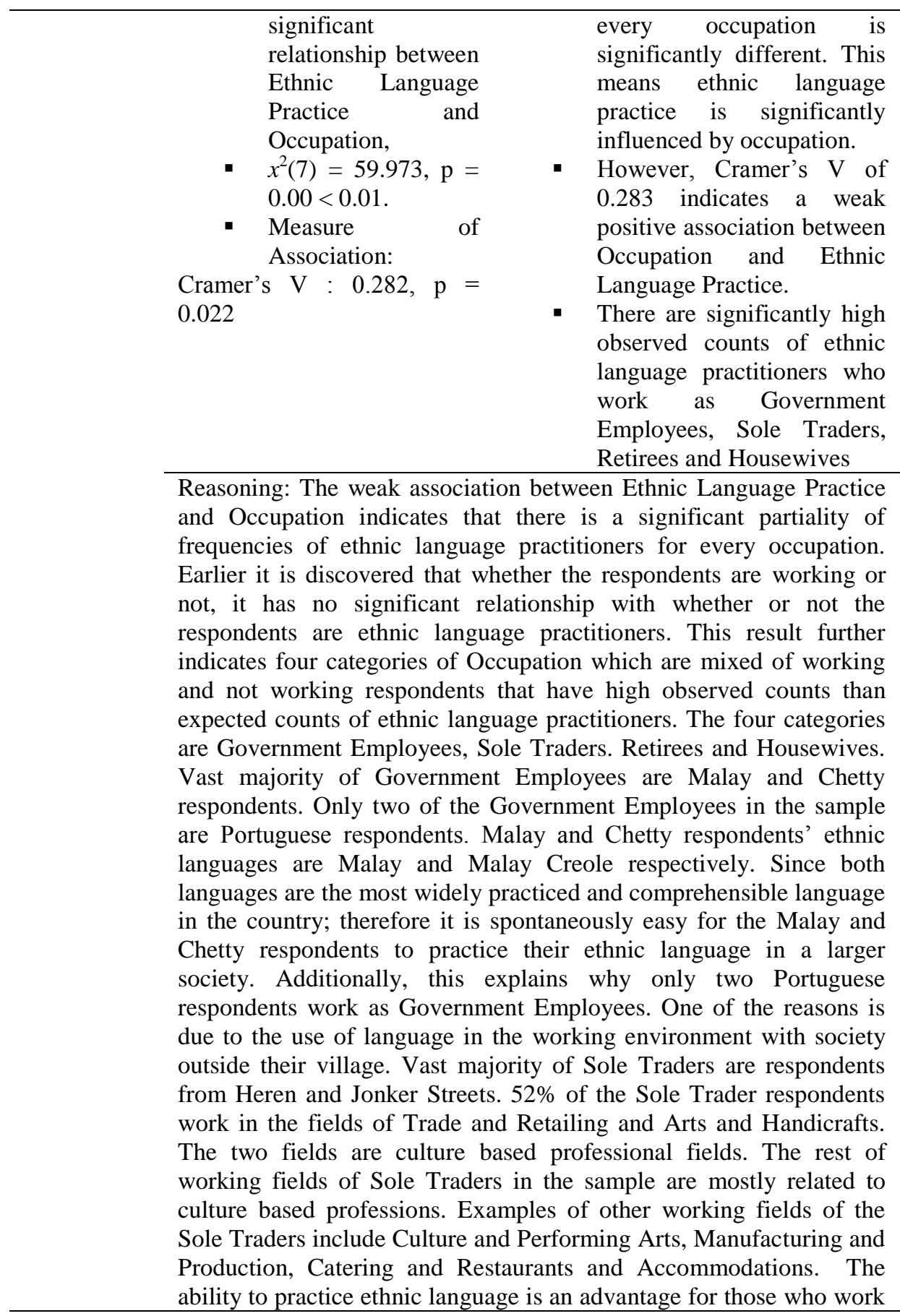


PLANNING MALAYSIA

in culture based professions. Thus this explains why vast majority of Sole Trader respondents practice their ethnic language. For Retirees and Housewives respondents, most of them spend their time at home or with families and their cultural community. One of the strong factors which can influence the tendency to speak ethnic language is the surrounding individuals a person interacts with. Since interaction with family and surrounding residents are likely more regular for Retirees and Housewives in comparison with other categories of Occupation, it is therefore unsurprising for majority of Retirees and Housewives of the cultural community to practice their ethnic language as spoken language.

Job

Promotes

Culture?

(Cultural

Based

Profession

/ Non-

Cultural

Based

Profession)
- There is a highly statistically significant relationship between Ethnic Language Practice and Job Promotes Culture,

- $x^{2}(1)=6.243, \mathrm{p}=$ $0.01<0.01$.

- Measure of Association:

Phi: $0.135, \mathrm{p}=0.000$

$$
\text { Phi: } 0.135, p=0.000
$$

- Frequency of ethnic language practitioners who have cultural based profession and non-cultural based profession is significantly different. This means ethnic language practice is significantly influenced by job promotes culture.

- However, Phi of 0.135 indicates a very weak positive association between Job Promotes Culture and Ethnic Language Practice.

- There are significantly high observed counts of ethnic language practitioners who have cultural based professions.

Reasoning: The strong association between Ethnic Language Practice and Job Promotes Culture indicates that ethnic language practitioners are likely those who work in cultural-based profession. Respondents who work in cultural based professions are likely those with professional expertise in cultural manifestation and tourism management. Since practice of ethnic language is significant in determining the strength of community bridge, to master in ethnic language practice is an advantage for the respondents with cultural based professions. First, this enables the respondents to make the most out of the interaction with individuals in the cultural community especially resourceful individuals who are cultural experts. Secondly, this enables the respondents to maximize understanding and skills in culture through ethnic conversational practice. Thirdly, the ability to converse well in ethnic language reflects skills and expertise in 
Aisyah Abu Bakar, Mariana Mohamed Osman, Syahriah Bachok \& Mansor Ibrahim

Analysis on Community Involvement in Cultural Activities: Transmission of Ethnic Language

culture of the professionals. Therefore it is expected for those with cultural based professions to acquire the ability to converse in their ethnic language.

\begin{tabular}{|c|c|}
\hline & $\begin{array}{l}\text { - Frequency of ethnic } \\
\text { language practitioners of } \\
\text { different education levels is } \\
\text { significantly different. This } \\
\text { means ethnic language } \\
\text { practice is significantly } \\
\text { influenced by education } \\
\text { levels. } \\
\text { However, Cramer's V of } \\
\text { 0.179 indicates a very weak } \\
\text { positive association between } \\
\text { Education Level and Ethnic } \\
\text { Language Practice. } \\
\text { There are significantly high } \\
\text { observed counts of ethnic } \\
\text { language practitioners who } \\
\text { have primary school } \\
\text { education attainment. }\end{array}$ \\
\hline Level & $\begin{array}{l}\text { Reasoning: A weak association between Ethnic Language Practice } \\
\text { and Education Level indicates that ethnic language practitioners are } \\
\text { likely those with low education attainment, although the likelihood is } \\
\text { not too convincing. Conversely, this implies that the chance for } \\
\text { individuals with high education level in the cultural community to } \\
\text { speak their ethnic language is unpromising. High education levels } \\
\text { enable the respondents to work in more demanding professions, thus } \\
\text { allow more interaction with larger society. It is possible for ethnic } \\
\text { language practice to deteriorate due to less interaction with cultural } \\
\text { community and more interaction with the larger and more general } \\
\text { society. Nevertheless, for the individuals in the cultural community to } \\
\text { obtain a high education level is equally important as protecting their } \\
\text { heritage. It is vital for the individuals in the ethnic minorities of } \\
\text { Malaysian citizens to move up in the general society through better } \\
\text { education attainment, not only for them to have access to more } \\
\text { opportunities to improve their way of living, but also for the larger } \\
\text { society to be conscious of the existence of the ethnic minorities. At } \\
\text { the same time, culture manifestation must also be upheld to sustain } \\
\text { the strength of the cultural roots. }\end{array}$ \\
\hline $\begin{array}{l}\text { Household } \\
\text { Income } \\
\text { Categories }\end{array}$ & $\begin{array}{lll}\text { There is a highly } & \text { Frequency of ethnic } \\
\text { statistically } & \text { language practitioners of } \\
\text { different household income } \\
\text { significant } & \text { categories is significantly } \\
\text { relationship between } & \text { different. This means ethnic } \\
\text { Ethnic Language } & \end{array}$ \\
\hline
\end{tabular}


PLANNING MALAYSIA

Journal of the Malaysia Institute of Planners (2014)

\begin{tabular}{|c|c|}
\hline & $\begin{array}{l}\text { language practice is } \\
\text { significantly influenced by } \\
\text { household income } \\
\text { categories. } \\
\text { Eta of - } 0.377 \text { indicates a } \\
\text { weak negative association } \\
\text { between Household Income } \\
\text { Categories and Ethnic } \\
\text { Language Practice. } \\
\text { There are significantly high } \\
\text { observed counts of ethnic } \\
\text { language practitioners who } \\
\text { have lower than RM } 4,000 \\
\text { household income. }\end{array}$ \\
\hline & $\begin{array}{l}\text { Reasoning: The negative yet weak association between Ethnic } \\
\text { Language Practice and Household Income Categories indicates that as } \\
\text { the respondents' household income increases, the more unlikely for } \\
\text { the respondents to practice ethnic language, although the likelihood is } \\
\text { not too convincing. The reasoning for Household Income Categories } \\
\text { is parallel to the reasoning in Education Level. Better education } \\
\text { attainment allows more job opportunities and higher income. Thus } \\
\text { household income correlates with education attainment. It is } \\
\text { previously pointed out that the higher the education level, the more } \\
\text { unlikely for the respondents to practice ethnic language. Both } \\
\text { education level and household income responds to socio-economic } \\
\text { status of the respondents. This implies that as the respondents move } \\
\text { up in the socio-economic status, ethnic language practice is likely to } \\
\text { deteriorate. This finding is alarming for the cultural community. This } \\
\text { is because for the cultural community to transmit their ethnic } \\
\text { language is equally as important as to improve their socio-economic } \\
\text { status. Alas, the finding proves otherwise. Therefore, among efforts to } \\
\text { sustain ethnic language practice, there must be unique or exclusive } \\
\text { approaches on individuals with high income and high education } \\
\text { attainment. }\end{array}$ \\
\hline $\begin{array}{l}\text { Household } \\
\text { Members } \\
\text { Categories }\end{array}$ & 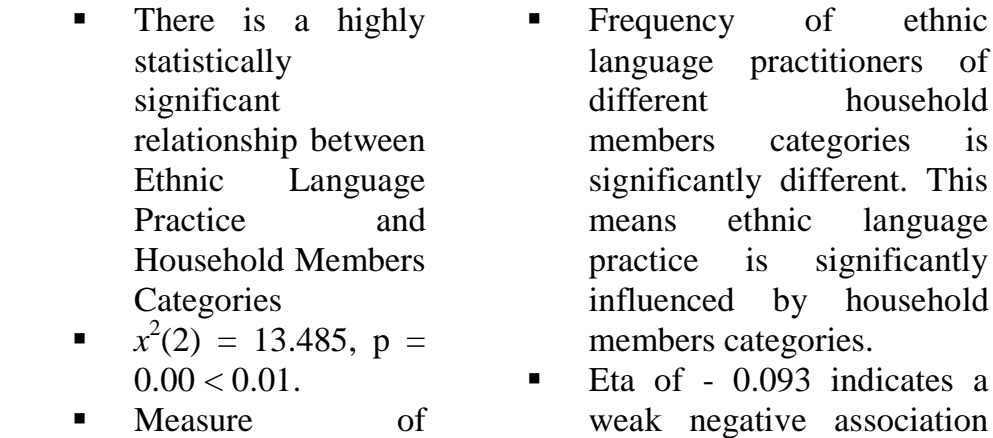 \\
\hline
\end{tabular}


Aisyah Abu Bakar, Mariana Mohamed Osman, Syahriah Bachok \& Mansor Ibrahim

Analysis on Community Involvement in Cultural Activities: Transmission of Ethnic Language

Eta: - 0.093

Association:

*The smaller the household members of the respondents, the more likely they practice ethnic language between Household Members Categories and Ethnic Language Practice.

- There are significantly high observed counts of ethnic language practitioners who have lower than five household members.

Reasoning: The negative yet very weak association between Ethnic Language Practice and Household Members Categories indicates that as the respondents' household members increases, the more unlikely for the respondents to practice ethnic language, although the likelihood is not too convincing. There are two ways to infer this finding. First, in response with latter reasoning, since household members categories correlate with household income categories, household members can also be used to determine socio-economic status. Therefore the reasoning for this analysis is similar to previous reasoning on household income. Secondly, as family members increases, there is a possibility that more variety of language is used to converse at home, thus reduce the use of ethnic language. This is because as individuals in the family socialize with the general society, chances of 'Language Shift' to occur are inevitable. Thus, when the individuals return home, there is a possibility that the ethnic language practiced in the family to be replaced by other languages. Therefore, the greater the amount of members in the family, the stronger is the likelihood of Language Shift to occur.

According to the reasoning of results in Table 18, characters of majority of ethnic language practitioners and non-practitioners in the cultural community can be distinguished. Table addresses the common characters of ethnic language practitioners and non-practitioners.

Table 18: Common Characters of Club Participants and Non-Participants

Common Characters of Respondents Who Are Drawn to be Practitioners of Ethnic Language

\begin{tabular}{ll}
\hline Marital Status & $:$ Married \\
\hline Age Categories & $:$ years old and above \\
\hline Location of Residence & $:$ Morten Village, Heren and Jonker Streets, Gajah \\
& Berang Village \\
\hline Origin & $:$ Non-Native \\
\hline Duration of Residence & 60 years and above
\end{tabular}


PLANNING MALAYSIA

Journal of the Malaysia Institute of Planners (2014)

\begin{tabular}{|c|c|}
\hline Categories & \\
\hline Ethnicity & : Malay, Chinese, Chetty \\
\hline Religion & : Islam, Buddhism, Hinduism \\
\hline Occupation & : Government, Sole Traders, Housewives, Retirees \\
\hline Job Promotes Culture & : Cultural Based Professions \\
\hline Education Level & : Primary Schools \\
\hline $\begin{array}{l}\text { Household } \quad \text { Income } \\
\text { Categories }\end{array}$ & : $\quad$ Below RM 4,000 \\
\hline $\begin{array}{l}\text { Household } \\
\text { Categories }\end{array}$ & : 5 Members and below \\
\hline
\end{tabular}

Common Characters of Respondents Who Are Drawn to be Non-Practitioners of Ethnic Language

\begin{tabular}{llll}
\hline Marital Status & $:$ Single & \\
\hline Age Categories & $:$ 40 years old and below & \\
\hline Location of Residence & $:$ Portuguese Village & \\
\hline Origin & $:$ Native & \\
\hline $\begin{array}{l}\text { Duration of Residence } \\
\text { Categories }\end{array}$ & Below 60 years & \\
\hline Ethnicity & $:$ Baba and Nyonya, Indians, Portuguese & \\
\hline Religion & $:$ Roman Catholic, Atheism & Students, \\
Occupation & $:$ Private Employees, Partnerships, & \\
\hline Job Promotes Culture & $:$ Non-Cultural Based Professions & \\
\hline Education Level & $:$ Secondary Schools, College, Bachelor Degree \\
\hline Household & $:$ Above RM 4,000 \\
Categories & & \\
\hline Household & & & \\
Categories & Members & & \\
\hline
\end{tabular}

The Chi-Square Analysis indicates that there are significant relationships between some demographic and socio-economic factors. Therefore, in order to implement efforts to enhance the practice of ethnic language, the focus groups are those who are drawn not to be non-practitioners of Ethnic Language.

\section{ANALYSIS ON PRACTICE OF LANGUAGE FORMS BASED ON AGE FACTOR}

Language Forms refer to practices and expressions which require strong command of Ethnic Language. In this research, there are 10 Language Forms to be analysed. The followings are the 10 Language Forms: 
Aisyah Abu Bakar, Mariana Mohamed Osman, Syahriah Bachok \& Mansor Ibrahim

Analysis on Community Involvement in Cultural Activities: Transmission of Ethnic Language

1. Accent and Dialect

2. Proverb and Idioms

3. Spiritual Religious

Passages

4. Spell Incantation

5. Traditional Songs
6. Nursery Rhymes

7. Poems Epic Songs

8. Riddles

9. Hereditary Tips

10. Myths and Legends

The respondents are inquired to address their practice regularity of 10 language forms. Each level of regularity is given scores for further statistical test.

Language Scores refers to a continuous variable which represent the sum of scores of practice regularity for each language forms. It is found that as age increases, the practice of language forms improves.

A Trend Analysis is implemented to observe the mean difference of Language Scores between younger age group, middle age group and older age group.

Table 19: Trend Analysis between 3 Ascending Age Categories and Language Scores

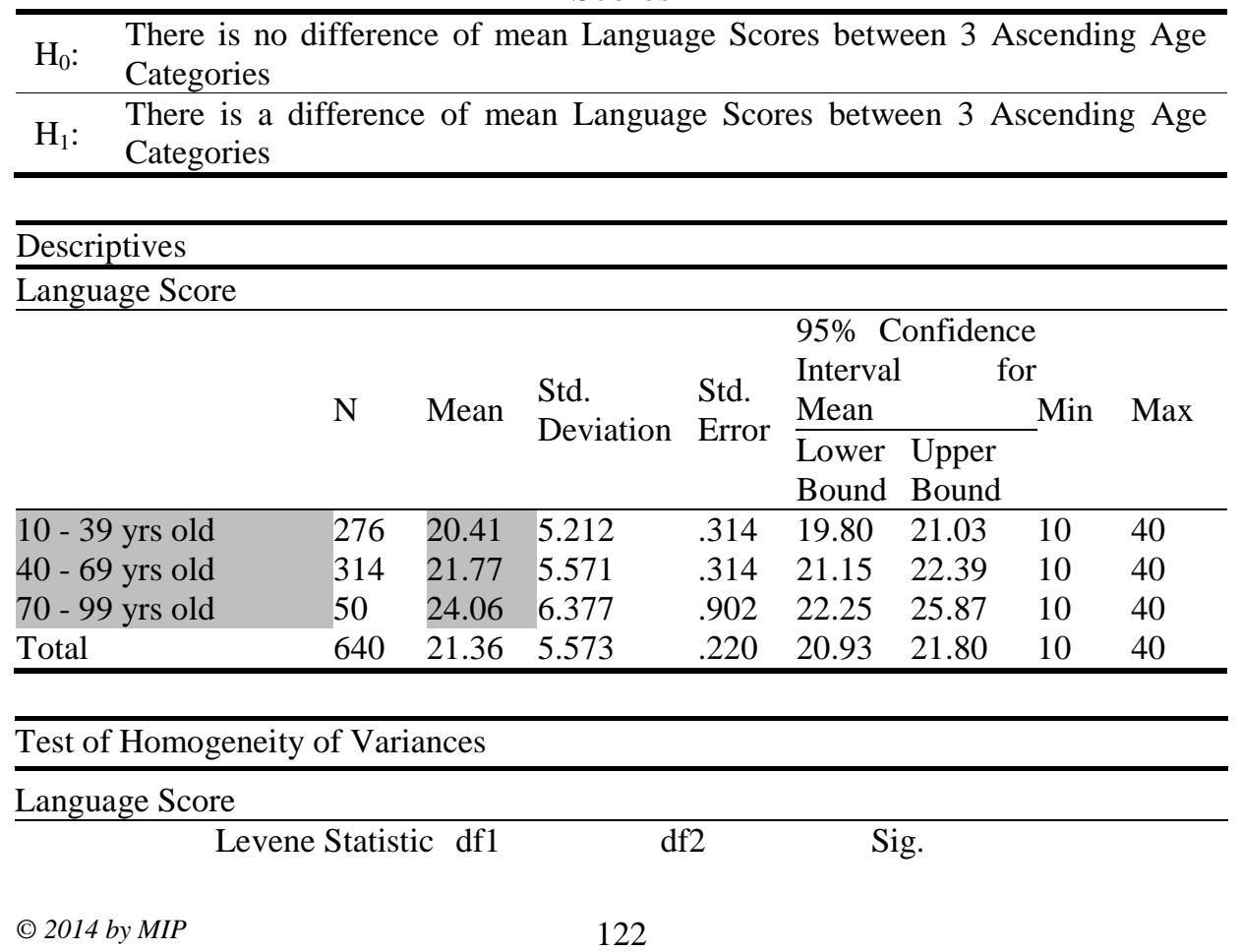


PLANNING MALAYSIA

Journal of the Malaysia Institute of Planners (2014)

\begin{tabular}{|c|c|c|c|c|c|c|c|}
\hline \multicolumn{8}{|l|}{ ANOVA } \\
\hline \multicolumn{8}{|c|}{ Language Score } \\
\hline & & & $\begin{array}{l}\text { Sum } \\
\text { Squares }\end{array}$ & $\mathrm{of}_{\mathrm{df}}$ & Mean Squ & & Sig. \\
\hline \multirow{4}{*}{$\begin{array}{l}\text { Between } \\
\text { Groups }\end{array}$} & \multicolumn{2}{|c|}{ (Combined) } & 664.950 & 2 & 332.475 & 11.042 & .000 \\
\hline & \multirow{3}{*}{$\begin{array}{l}\text { Linear } \\
\text { Term }\end{array}$} & Unweighted & 563.018 & 1 & 563.018 & 18.700 & .000 \\
\hline & & Weighted & 641.080 & 1 & 641.080 & 21.292 & .000 \\
\hline & & Deviation & 23.870 & 1 & 23.870 & .793 & .374 \\
\hline \multirow{2}{*}{\multicolumn{3}{|c|}{$\begin{array}{l}\text { Within Groups } \\
\text { Total }\end{array}$}} & 19179.223 & 637 & 30.109 & & \\
\hline & & & 19844.173 & 639 & & & \\
\hline
\end{tabular}

The Trend Analysis produces three consecutive tables. The Desciptives table shows that as the age categories increase in continuum, the language scores also increases. Levene's test for homogeneity of variances is not significant $(\mathrm{p}=0.345>0.05)$, indicating that the assumption of homogeneity has not been violated. The Anova table shows a significant between-groups F-ratio $(\mathrm{p}=0.000019<0.05)$, thus it can be concluded that Language Score differs significantly across the age categories, $\mathrm{F}(2,637)=11.042, \mathrm{p}<0.05$. Therefore rejects the null hypothesis, which means there is a significant difference of mean language scores between 3 ascending age categories. Furthermore, by examining the linear term, which is also significant ( $\mathrm{p}<$ 0.05 ), it can be concluded that language score increases consistently across age categories. An illustration of this linear trend can be observed in Figure 25.

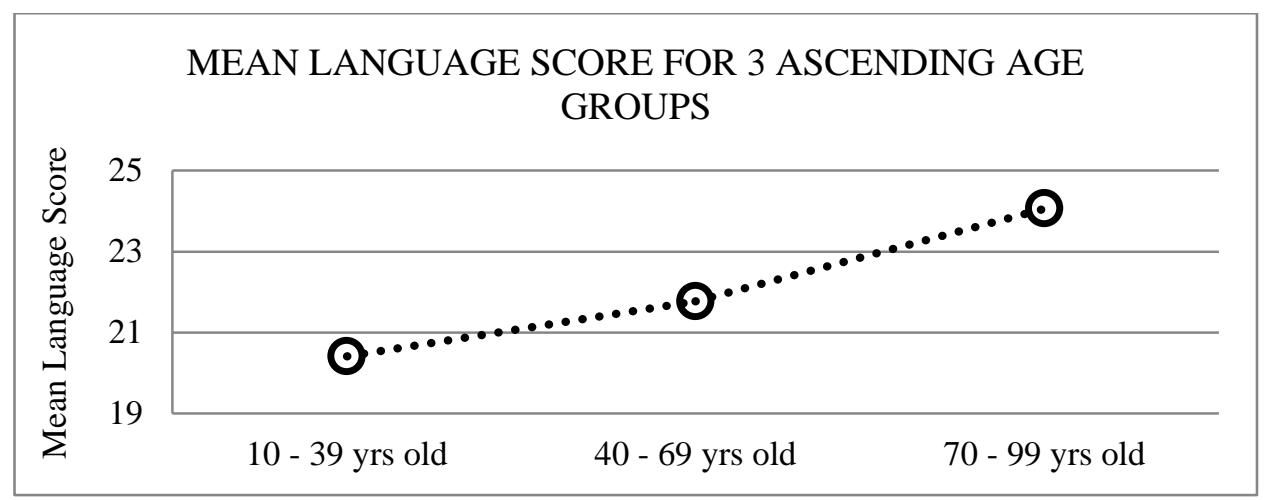

Figure 25: Linear Trend of Language Score across 3 Ascending Age Categories 
Aisyah Abu Bakar, Mariana Mohamed Osman, Syahriah Bachok \& Mansor Ibrahim

Analysis on Community Involvement in Cultural Activities: Transmission of Ethnic Language

Figure 25 shows a linear relationship between the three age categories and language score. As age increases in continuum, the Language Scores also increases. Thus, the older respondents are likely to gain high language scores than younger respondents.

For more accurate result, a correlation test on a continuous Age variable and Language Score variable has been implemented beforehand. The analysis yields a low correlation value, $r=0.153$. This suggests a possibility of interfering factors which have weakened the relationship. Since Language Score is the total score of practice regularity for 10 language forms, there is a chance that for a few language forms, age has no effect on the practice regularity score. That is, for some language forms, respondents from older age categories do not score higher than respondents from younger age categories. A Multivariate Anova is conducted to observe the significant differences of mean practice regularity score of each 10 language forms for 3 ascending age categories.

Table 20: Multivariate Anova [Manova] to Compare Practice Regularity Score of 10 Language Forms between 3 Ascending Age Categories

\begin{tabular}{ll}
\hline $\mathrm{H}_{0}:$ & $\begin{array}{l}\text { There is no significant differences of Mean Practice Regularity Score for } 10 \\
\text { Language Forms between the } 3 \text { Ascending Age Categories }\end{array}$ \\
\hline $\mathrm{H}_{1}:$ & $\begin{array}{l}\text { There are significant differences of Mean Practice Regularity Score for } 10 \\
\text { Language Forms between the } 3 \text { Ascending Age Categories }\end{array}$ \\
\hline
\end{tabular}

\begin{tabular}{lllll}
\hline Descriptive Statistics & & & & \\
\hline Language Forms & Age Categories & Mean & Std. Deviation & N \\
\hline \multirow{4}{*}{ Accent \& Dialect } & $10-39$ yrs old & 2.78 & 1.019 & 276 \\
& $40-69$ yrs old & 2.90 & 1.077 & 314 \\
& $70-99$ yrs old & 3.40 & .969 & 50 \\
& Total & 2.89 & 1.055 & 640 \\
\hline \multirow{5}{*}{ Proverb \& Idiom } & $10-39$ yrs old & 1.89 & .767 & 276 \\
& $40-69$ yrs old & 2.19 & .841 & 314 \\
& $70-99$ yrs old & 2.36 & 1.005 & 50 \\
Spiritual & Total & 2.08 & .839 & 640 \\
Passages & $10-39$ yrs old & 2.17 & .974 & 276 \\
& Religious40 - 69 yrs old & 2.40 & .981 & 314 \\
& $70-99$ yrs old & 2.68 & .978 & 50 \\
\multirow{5}{*}{ Spell Incantation } & Total & 2.32 & .988 & 640 \\
& $10-39$ yrs old & 1.84 & .930 & 276 \\
& $40-69$ yrs old & 1.89 & .972 & 314 \\
& $70-99$ yrs old & 2.12 & .872 & 50 \\
& Total & 1.88 & .948 & 640 \\
\hline
\end{tabular}


PLANNING MALAYSIA

Journal of the Malaysia Institute of Planners (2014)

\begin{tabular}{lllll}
\hline \multirow{4}{*}{ Traditional Songs } & $10-39$ yrs old & 2.22 & .831 & 276 \\
& $40-69$ yrs old & 2.28 & .864 & 314 \\
& $70-99$ yrs old & 2.18 & .896 & 50 \\
& Total & 2.25 & .852 & 640 \\
\hline \multirow{5}{*}{ Nursery Rhymes } & $10-39$ yrs old & 2.01 & .813 & 276 \\
& $40-69$ yrs old & 1.95 & .798 & 314 \\
& $70-99$ yrs old & 1.92 & .804 & 50 \\
& Total & 1.97 & .805 & 640 \\
\hline \multirow{5}{*}{ Poems Epic Songs } & $10-39$ yrs old & 1.97 & .802 & 276 \\
& $40-69$ yrs old & 2.07 & .818 & 314 \\
& $70-99$ yrs old & 2.48 & .762 & 50 \\
Riddles & Total & 2.06 & .816 & 640 \\
\hline & $10-39$ yrs old & 1.69 & .710 & 276 \\
& $40-69$ yrs old & 1.81 & .707 & 314 \\
& $70-99$ yrs old & 2.22 & .815 & 50 \\
Hereditary Tips & Total & 1.79 & .729 & 640 \\
\hline & $10-39$ yrs old & 2.01 & .822 & 276 \\
& $40-69$ yrs old & 2.34 & .850 & 314 \\
& $70-99$ yrs old & 2.46 & .973 & 50 \\
& Total & 2.20 & .865 & 640 \\
\hline \multirow{5}{*}{ Myths \& Legends } & $10-39$ yrs old & 1.83 & .762 & 276 \\
& $40-69$ yrs old & 1.94 & .754 & 314 \\
& $70-99$ yrs old & 2.24 & .894 & 50 \\
& Total & 1.91 & .775 & 640 \\
\hline
\end{tabular}

\begin{tabular}{|c|c|c|c|c|c|c|}
\hline \multicolumn{7}{|c|}{ Multivariate Tests } \\
\hline \multicolumn{2}{|c|}{ Effect } & Value & $\mathrm{F}$ & \multirow{2}{*}{$\begin{array}{l}\text { Hypothesis df } \\
10.000\end{array}$} & \multirow{2}{*}{$\begin{array}{l}\text { Error df } \\
628.000\end{array}$} & \multirow{2}{*}{$\begin{array}{l}\text { Sig. } \\
.000\end{array}$} \\
\hline \multicolumn{2}{|l|}{ Intercept } & .899 & $558.510^{\mathrm{b}}$ & & & \\
\hline $\begin{array}{l}\text { (Age } \\
\text { Categories) } \\
\text { Range } 30 \mathrm{Y}\end{array}$ & $\begin{array}{l}\text { Pillai's Trace } \\
\text { ears }\end{array}$ & .153 & 5.199 & 20.000 & 1258.000 & .000 \\
\hline \multicolumn{7}{|c|}{ Tests of Between-Subjects Effects } \\
\hline Source & Dependent Variable & \multicolumn{2}{|c|}{$\begin{array}{l}\text { Type III Sum } \\
\text { of Squares }\end{array}$} & $\begin{array}{l}\text { Mean } \\
\text { Square }\end{array}$ & $\mathrm{F}$ & Sig. \\
\hline \multirow{8}{*}{$\begin{array}{l}\text { Age } \\
\text { Categories } \\
\text { (Range } \\
\text { Years) }\end{array}$} & -Accent\&Dialect & \multicolumn{2}{|c|}{16.472} & 8.236 & 7.552 & .001 \\
\hline & -Proverb\&Idiom & \multicolumn{2}{|c|}{17.471} & 8.736 & 12.862 & .000 \\
\hline & -Spiritual\&Rel Pass & \multicolumn{2}{|c|}{14.733} & 7.366 & 7.701 & .000 \\
\hline & -Spell\&Incantation & \multicolumn{2}{|c|}{3.395} & 1.698 & 1.894 & 151 \\
\hline & 30-TraditionalSongs & \multicolumn{2}{|c|}{.774} & .387 & .532 & .588 \\
\hline & -NurseryRhymes & \multicolumn{2}{|c|}{.793} & .397 & 612 & .543 \\
\hline & -Poems\&EpicSongs & \multicolumn{2}{|c|}{11.193} & 5.596 & 8.595 & .000 \\
\hline & & & & 11.661 & .000 \\
\hline
\end{tabular}


Aisyah Abu Bakar, Mariana Mohamed Osman, Syahriah Bachok \& Mansor Ibrahim

Analysis on Community Involvement in Cultural Activities: Transmission of Ethnic Language

\begin{tabular}{lllllll} 
& -HereditaryTips & 19.564 & 2 & 9.782 & 13.587 & .000 \\
-MythsLegends & 7.651 & 2 & 3.825 & 6.470 & .002 \\
\hline \multirow{4}{*}{ Error } & -Accent\&Dialect & 694.652 & 637 & 1.091 & & \\
-Proverb\&Idiom & 432.623 & 637 & .679 & & \\
-Spiritual\&Rel Pass & 609.316 & 637 & .957 & & \\
-Spell\&Incantation & 570.816 & 637 & .896 & & \\
& -TraditionalSongs & 463.226 & 637 & .727 & & \\
-NurseryRhymes & 412.807 & 637 & .648 & & \\
-Poems\&EpicSongs & 414.782 & 637 & .651 & & \\
& -Riddles & 327.937 & 637 & .515 & & \\
--HereditaryTips & 458.622 & 637 & .720 & & \\
-MythsLegends & 376.622 & 637 & .591 & & \\
\hline
\end{tabular}

The Manova test produces three important tables. The followings explain these three tables.

\section{Descriptive Statistics Table}

Descriptive Statistics shows mean scores of practice regularity of 10 language forms between 3 age categories which increase in continuum.

- cells indicate the language forms which have statistically significant difference in practice regularity between age categories and increase in mean score of practice regularity as the age categories ascend.

- cell which belongs to Spell and Incantation shows an increase of mean score of practice regularity as the age categories ascend, however the differences of the mean scores between the age categories are not statistically significant.

- cells which belong to Traditional Songs and Nursery Rhymes indicate language forms which have no statistically significant differences of mean scores of practice regularity between the ascending age categories.

Therefore, based on the Descriptive Statistics, it is discovered that there are two language forms which affect the positive relationship of Language Score and Age. They are Traditional Songs and Nursery Rhymes. 
PLANNING MALAYSIA

Journal of the Malaysia Institute of Planners (2014)

\section{Multivariate Tests Table}

According to Multivariate Tests table, the highlighted significant value suggests that there is an effect of the 3 Age Categories towards the mean of Practice Regularity Score, F $(20,1258)=5.199, \mathrm{p}<0.005$

\section{Test of Between-Subjects Effects}

Tests of Between-Subjects Effects table indicates that there are seven language forms as highlighted in yellow which have $\mathrm{p}$ value $<0.005$. This shows that there are significant differences of mean score of practice regularity of the seven language forms between the ascending age categories.

However, there are also three language forms as highlighted in red which have $\mathrm{p}$ value $>0.005$. This shows that there are no significant differences of mean score of practice regularity of the three language forms between the ascending age categories. These language forms are Spell and Incantation, Traditional Songs and Nursery Rhymes. Table 2.6 is the overall result Manova test.

Table 21: Interpretation of Manova Results of Mean Scores Practice Regularity for 10 Language Forms between 3 Ascending Age categories

\begin{tabular}{|c|c|c|c|}
\hline \multicolumn{4}{|c|}{ RESULTS OF MANOVA (Between Subject Effects) } \\
\hline $\mathrm{P}<0.005$ & & $P>0.005$ & \\
\hline Accent \& Dialect & $\begin{array}{l}F(2,637)=7.552, p \\
=.001\end{array}$ & $\begin{array}{l}\text { Spell \& } \\
\text { Incantation }\end{array}$ & $\begin{array}{l}\mathrm{F}(2,637)=1.894, \mathrm{p} \\
=.151\end{array}$ \\
\hline Proverb \& idioms & $\begin{array}{l}F(2,637)=12.68, p \\
=.000\end{array}$ & $\begin{array}{l}\text { Traditional } \\
\text { Songs }\end{array}$ & $\begin{array}{l}F(2,637)=0.532, p \\
=.588\end{array}$ \\
\hline Spiritual \& Rel. & $\mathrm{F}(2,637)=7.701, \mathrm{p}$ & Nursery & $F(2,637)=0.612, p$ \\
\hline Pass. & $=.000$ & Rhymes & $=.543$ \\
\hline Poems \& Epic & $\mathrm{F}(2,637)=8.595, \mathrm{p}$ & & \\
\hline Riddles & $\begin{array}{l}F(2,637)=11.66, p \\
=.000\end{array}$ & & \\
\hline Hereditary Tips & $\begin{array}{l}F(2,637)=12.59, p \\
=.000\end{array}$ & & \\
\hline Myths \& & $\mathrm{F}(2,637)=6.470, \mathrm{p}$ & & \\
\hline Legends & $=.002$ & & \\
\hline
\end{tabular}


Aisyah Abu Bakar, Mariana Mohamed Osman, Syahriah Bachok \& Mansor Ibrahim

Analysis on Community Involvement in Cultural Activities: Transmission of Ethnic Language

Since there are differences of mean found between subjects in the Manova test, the null hypothesis is therefore rejected. This means that there are statistically significant differences of Mean Practice Regularity Score for 10 Language Forms between the 3 Ascending Age Categories.

Up to this point, the statistical tests indicate that age influences practice regularity of most Language Forms and the overall Language Score. The statistical tests suggest that the older the respondents, the more regularly they practice their expressions of Language Forms, though some expressions of Language Forms indicate differently, especially Nursery Rhymes and Traditional Songs. These language forms have weakened the positive relationship between age and overall language score. However, at the same time this suggest that either the older respondents are showing lesser interest than younger respondents in expressing some of the language forms or the younger respondents are showing greater interests and commitment than older respondents in expressing some of the language forms. If this is the case, then different age categories have different interest, awareness and commitment in practice in different language forms. Then again, this outcome generalizes only on age categories for all respondents regardless of other demographic and socio-economic factors.

\section{LANGUAGE EXPERIENCES AND INFLUENCES ON COMMUNAL ACTIVITIES}

The respondents are inquired to address their level of three types of experience in the 10 Language Forms. These types of experiences are Exposure to Language Forms, Training of Language Forms and Knowledge on the basis of the Language Forms. The research attempts to determine the correlation between the three types of Language Experiences Score and Language Scores. A Pearson Correlation is implemented for this assessment.

Table 22: Pearson's Correlation Test of Language Score and Three Language Experiences

\begin{tabular}{llll}
\hline $\mathrm{H}_{0}:$ & $\begin{array}{l}\text { There are no significant correlations between the } 3 \text { types of Language } \\
\text { Experiences and Language Scores }\end{array}$ \\
\hline $\mathrm{H}_{1}:$ & $\begin{array}{l}\text { There are significant correlations between the } 3 \text { types of Language Experiences } \\
\text { and Language Scores }\end{array}$ \\
\hline \multicolumn{5}{c}{$\begin{array}{l}\text { Language } \\
\text { Score }\end{array}$} & Language Experiences Score \\
\hline
\end{tabular}


PLANNING MALAYSIA

Journal of the Malaysia Institute of Planners (2014)

\begin{tabular}{lllccc}
\hline Language & Pearson Correlation & 1 & $.504^{* *}$ & $.498^{* *}$ & $.502^{\text {** }}$ \\
\cline { 2 - 5 } Score & Sig. (2-tailed) & & .000 & .000 & .000 \\
\cline { 2 - 5 } & $\mathrm{N}$ & 640 & 640 & 640 & 640 \\
\hline
\end{tabular}

**. Correlation is significant at the 0.01 level (2-tailed).

According to Table, all $\mathrm{p}$ values are less than 0.01 which imply that there are high level statistically significant correlations between the three types of Language Experiences and Language Score, Exposure $(r=0.505, p<0.01)$, Trained $(\mathrm{r}=0.498, \mathrm{p}<0.01)$ and Informed $(\mathrm{r}=0.502, \mathrm{p}<0.01)$. This implies that there are positive correlations between Language Experiences and Language Scores. Since all correlations' figures are between 0.4 and 0.6 , all correlations' strengths are considered moderate. This means that language experiences moderately influence Language Scores. There are other factors which influence Language Scores such as Practice of Ethnic Language, Demographic and Socio-Economic Factors which are highlighted earlier.

The significances of Oral Traditions are reflected in respondents' level of involvement in cultural and communal activities. The respondents are inquired to address their regularity in attending community gathering and rate their commitment towards their cultural community. Additionally, at the end of the questionnaire, the respondents are asked to address their level of awareness and involvement in their cultural activities. All of the respondents' statements on the four mentioned inquiries are measured in Anchored 5 point scale.

Language Experience Score is the sum of scores for the three types of Language Experiences mentioned earlier. The research attempts to observe the impacts of Language Score and Language Experience Score towards regularity in attending community gathering, commitment towards cultural community, awareness of cultural activities and involvement in cultural activities. 
Aisyah Abu Bakar, Mariana Mohamed Osman, Syahriah Bachok \& Mansor Ibrahim

Analysis on Community Involvement in Cultural Activities: Transmission of Ethnic Language

Table 23: Correlation of Language Experience Score, Language Score, Community Gathering, Commitment towards Community, Awareness and Involvement in Cultural Activities

\begin{tabular}{|c|c|c|c|c|c|}
\hline & & $\begin{array}{l}\text { Attendance } \\
\text { Community } \\
\text { Gathering }\end{array}$ & $\begin{array}{l}\text { Commitment } \\
\text { towards } \\
\text { Community }\end{array}$ & Awareness & Involvement \\
\hline \multirow{3}{*}{$\begin{array}{l}\text { Language } \\
\text { Score }\end{array}$} & \multicolumn{2}{|c|}{ Pearson Correlation. $293^{* *}$} & $.356^{* *}$ & $.407^{* *}$ & $.455^{* *}$ \\
\hline & Sig. (2-tailed) & .000 & .000 & .000 & .000 \\
\hline & $\mathrm{N}$ & 640 & 640 & 640 & 640 \\
\hline \multirow{3}{*}{$\begin{array}{l}\text { Language } \\
\text { Experience } \\
\text { Score }\end{array}$} & Pearson Correlation & $182^{* *}$ & $.207^{* * *}$ & $.512^{* *}$ & $.451^{* *}$ \\
\hline & Sig. (2-tailed) & .000 & .000 & .000 & .000 \\
\hline & $\mathrm{N}$ & 640 & 640 & 640 & 640 \\
\hline
\end{tabular}

**. Correlation is significant at the 0.01 level (2-tailed).

Based on Table, all $\mathrm{p}$ values are less than 0.001 which implies that there are high level statistically significant correlations between every two variables being compared. All correlations display positive values which suggest that the increase of any of the variables influence the increase of other variables. However, none of the correlations are considered as strong correlations. Attendance Community Gathering and Commitment Community have low correlations with Language Score and Language Experience Score, while Awareness and Involvement variables have moderate correlations with Language Score and Language Experience Score.

According to Language Score row, the highest correlation value is Involvement variable $\left(\mathrm{r}=0.455, \mathrm{r}^{2}=0.21\right)$, followed by Awareness $(\mathrm{r}=$ $\left.0.407, r^{2}=0.17\right)$, Commitment Community $\left(r=0.356, r^{2}=0.13\right)$ and Community Gathering $\left(r=0.293, r^{2}=0.09\right)$ respectively. This suggests that among the four, the highest percentage that can be attributed to Language Scores is Involvement variable, which is $21 \%$. The remaining percentage of Language Scores is attributed to other variables. This means that $21 \%$ of Language Score affect Involvement in Cultural Activities.

On the other hand, for Language Experience Score, the highest correlation value is Awareness variable $(r=0.512, r 2=0.26)$, followed by Involvement $\left(r=0.451, r^{2}=0.20\right)$, Commitment Community $\left(r=0.207, r^{2}=\right.$ $0.04)$ and Community Gathering $\left(r=0.182, r^{2}=0.03\right)$ respectively. This suggests that among the four, the highest percentage that can be attributed to Total Experiences is Awareness variable, which is 26\%. The remaining percentage of Language Experience Score is attributed to other variables. 
This means that $26 \%$ of Language Experience Score affect Awareness in Cultural Activities.

This finding infers that in order for the respondents to be more involved in cultural activities, they have to practice their language forms and expressions more regularly. As well as that, in order for the respondents to have high awareness level of their cultural activities, they have to gain better knowledge and experience of their cultural language expression.

\section{CONCLUSION}

This paper reviews the significance of community character to practice of ethnic language and cultural language forms. It is found that community characters specifically referring to demographic and socio-economic factors influence the practice of their oral traditions. For cultural communities in Malacca, ethnicity and religion are two drivers of social geography. Thus expression of culture can be distinguished by locations since location represents majority of ethnicity and religion. Among the significant factors which affect ethnic language practice are Age, Location of Residence, Origin, Duration of residence, Ethnicity, Religion, Occupation, Job Promotes Culture, Education Levels, Household Income and Household Members. It is also found that Age significantly affects the level of practice regularity of cultural language forms. As the respondents grow older, it is more likely of them to practice their ethnic language forms. However, younger respondents have shown interests to practice Traditional Songs and Nursery Rhymes more than older respondents.

Language is an important tool to ensure cultural heritage such as traditional wisdom and folklores are transmitted in the most genuine manner. As mentioned by Shigemoto (2003), "A language is the culmination of thousands of years of a people's experience and wisdom. Moreover, it is the vehicle that transmits and perpetuates that wisdom." (Shigemoto, J, 2003). Language is intricately combined with a unique view of the world, belief system, culture and literature.

The surge of increasing homogenization of places causes the loss of distinctiveness and diversity which used to make lives interesting and profound. By understanding history and heritage through arts, celebrations and sharing institutions will strengthen a sense of cultural identity and distinctiveness of a place. Diversity promotes economic health as it fosters opportunity while non-diversity offers little prospect for future expansion, 
Aisyah Abu Bakar, Mariana Mohamed Osman, Syahriah Bachok \& Mansor Ibrahim

Analysis on Community Involvement in Cultural Activities: Transmission of Ethnic Language

either in the form of personal growth or economic development. Designing for diversity combines the aesthetic interest of urban design with social objectives of urban planning. Sustainability rests on the ability of people to be involved in the contribution to the well-being of the society. Community's opinions and perspectives must be regarded as important information in decision making processes. The involvement of the community in the significant cultural activities of a place heightens integration of social, political and economic aspects of the place (ICHC (2003), Newman P. \& Jennings, I. (2008) \& UNESCO (2003)). The future direction of this analysis is the assessment of community involvement in the remaining four domains of Intangible Cultural Heritage. They are Performing Arts, Knowledge, Social Practices and Traditional Craftsmanship. The involvement levels are analysed based on preferences and regularity of customary cultural expressions and practices.

\section{REFERENCES}

Asmah, O. (2004). The encyclopedia of Malaysia. Vol. 9: Languages and Literature. Singapore: Archipelago.

Huebner, T. (1987). A socio-historical approach to literacy development: A comparative case study from the Pacific. In J.A. Langer (Ed.), Language, literacy, and culture: Issues of society and schooling. (pp. 178-196). Norwood, New Jersey: Ablex Publishing Co.

Intangible Cultural Heritage Convention (ICHC). 2003. The Convention for the Safeguarding of Intangible Cultural Heritage. Retrieved January 4, 2011. http://www.unesco.org/culture/ich

Newman, P., \& Jennings, I. (2008). Cities as Sustainable Ecosystem. Principles and Practices. Washington D.C.: Island Press.

Shigemoto, J. (2003). Language Change and Language Planning Policy. Retrieved October 4, 2011. http://www.prel.org/products/products/language-change.pdf

United Nations Educational, Scientific and Cultural Organization (UNESCO). 2003. Implementing the Convention for the Safeguarding of Intangible Cultural Heritage. 